\title{
PIK3CB Gene Amplification
}

National Cancer Institute

\section{Source}

National Cancer Institute. PIK3CB Gene Amplification. NCI Thesaurus. Code C141339.

A molecular genetic abnormality indicating the presence of multiple copies of the PIK3CB gene. 